\title{
Abuse of Discretionary Powers in Administrative Law. Evolution of the Judicial Review Models: from "Administrative Morality" to the Principle of Proportionality"
}

\author{
Jerzy Parchomiuk ${ }^{* *}$
}

\begin{abstract}
Abuse of power is one of classic concepts in administrative law. According to the classical approach, this concept is based on the assumption that the scope of discretion of public administration bodies is defined, beside competence norms, procedural and legal grounds for action, also by the objective for which the discretionary powers was granted. The classic concept has evolved over the years. It is also evident that its importance has been in decline nowadays. The priority objectives of my study concerned more practical than theoretical aspects of the topic. The key issue of my work is to analyze how courts have changed their approach to the judicial review of the discretionary powers of public administration. I set myself two goals in this study: first, I would like to indicate the fundamental direction in which the classic concept of abuse of power evolves. Secondly, I would like to describe the contemporary role of this concept and to response whether it can still be an effective instrument to protect an individual from arbitrary decisions of the public administration.
\end{abstract}

Keywords

Discretionary Powers; Abuse of Power; Principle of Proportionality; Excess of Power; Ultra Vires; Judicial Self-restraint.

\section{Introduction: Public administration between binding and freedom of action}

The problem of binding and freedom of administration is one of the most contentious issues of administrative law (questio diabolica). It's about finding a balance between two conflicting goals. On the one hand, the administration must have a certain scope of freedom to carry out its tasks. On the other hand, excessive freedom granted to the administration can lead to violations of the fundamental rights of an individual.

The key element of the guarantee of individual freedom is judicial review of public administration. Therefore, it is a matter of dispute to which extent the public administration is subject to judicial review when performing the tasks entrusted. It is about

\footnotetext{
* The paper was prepared as part of the research project „Abuse of Rights in Administrative Law“, financed from funds of the National Science Centre, Poland (Ref. UMO-2015/17/B/HS5/00430).

** Jerzy Parchomiuk, Ph.D., Assistant Professor, Department of Administrative Law, The John Paul II Catholic University, Lublin, Poland E-mail: parchom@kul.pl
} 
appropriate separation of functions: the public administration is to implement the administrative policy, while the role of administrative courts is to review whether this function is correctly exercised under the legal provisions governing the activity of the administration. The consequence of separation of these functions is that the judicial review is limited to the criterion of legality and that the court's function to directly correct administrative decisions is waived. Due to the separation of functions, the court cannot substitute the administrative body, and it cannot take a discretionary ruling instead of the ruling the body has issued under its discretionary power ${ }^{1}$. The key question is who has the decisive voice, and who makes the final decision (Letztentscheidung)? ${ }^{2}$

The whole doctrine of errors in discretionary powers, and the concept of abuse of discretionary powers constituting its element, is a way of search for the right balance between the freedom of action and the fact the administration is bound with law.

The key issue of my work is to analyze how the courts have changed their approach to the judicial review of discretionary powers of public administration. The priority objectives of my study concerned more practical than legal aspects of the topic.

Due to the limited scope of the article, I cannot make too much detailed considerations. For this reason, I focus on the model analysis: I try to point out some basic trends in case law. With this model, I focus on the analysis of the basic evolutionary tendencies in the legal systems I consider to be the most representative (German, French and English) because of the impact they have had on case-law and scholarly opinion in other systems. For the same reasons, I give up the analysis of the abuse of powers in the sphere of the use of indefinite terms. It is a comprehensive issue, characterized by specific features and requiring a separate study.

\section{The essence of the problem - abuse as the application of discretionary powers contrary to their intended purpose}

The scholarly approach to the problem of abuse of discretionary powers in various legal systems is diverse. Regardless of some differences, the essence of the problem is similar in all legal systems. All the legal constructs based on the concept of abuse of discretionary powers use a teleological element: the abuse is an authority's error in the exercise of discretion in a way inconsistent with the intended purpose this sphere of freedom of action was granted for. The purpose should be determined based on a teleological interpretation of the competence norm.

1 German Federal Administrative Court: 9 Mai 1956 (III C 123.54, BVerwGE 3, 279); WOLFF, Hans J., Otto BACHOF and Rolf STOBER. Verwaltungsrecht I. München: C. H. Beck, 1994, p. 378. ISBN 3-40608061-8; HÄFELIN, Ulrich and Georg MÜLLER. Grundriss des Allgemeinen Verwaltungsrechts, Zürich: Schulthess, 1998, p. 93-94. ISBN 3-7255-3778-X; RODE, Lars-Henrik. \ 40 VwVfG und die deutsche Ermessenslebre, Frankfurt am Main: Peter Lang, 2003, pp. 95-98. ISBN 3-631-50308-3.

2 MAURER, Hartmut. Allgemeines Verwaltungsrecht. München: C. H.Beck, 2011, p. 142. ISBN 978-3-406-61452-1. 
All public administration activities are "teleologically determined". In contrast to an individual who can freely choose the purpose of his or her actions, the public administration must pursue specific objectives set by public tasks. Each competence to act within discretionary power was entrusted by the legislature for the pursue of specific objectives. This thesis is referred to as "purpose axiom". It is the administrative body's obligation to implement the purpose of the act, the body may not pursue an objective other than set by the legislature. If the body is guided by other reasons, or where it points to the alleged fulfilment of the legitimate objective in order to hide the actual intentions, then its decision is unlawful, illegal ${ }^{3}$.

The EU administrative law also points out that the political freedom of the EU institutions is very much determined on a teleological basis, even more than it is for national authorities. For these reasons, EU bodies are not vested with overall, all-embracing powers, but specific powers. Secondly, these powers are strictly purpose bound ${ }^{4}$.

The purpose-bound character of powers may form an important source of their limitation. On the other hand, there are certain factors that determine a very wide range of discretionary powers of the EU institutions. First of all, objectives to be pursued by the EU institutions can not be too strictly defined as there is a need to find a broad political compromise when negotiating and concluding the treaties. Secondly, sources of the powers are mainly of political nature, and this means that the EU institutions should themselves determine, within defined limits, the directions of the policy to be pursued. Thirdly, a wide margin of discretion is necessary due to the fact that the conditions in which these decisions are being made are enormously complex. The number of factors to be taken into account by the EU institutions often exceeds the complexity of the problems faced by national authorities. Consequently, judicial review is similar to the review of reasonableness (German: Vertretbarkeit) of a discretionary decision ${ }^{5}$.

The EU courts have pointed out that Community institutions enjoy a margin of discretion in the choice of the means needed to carry out their policies under the treaties. This is particularly true for activities undertaken in the field of the common organization of the markets whose purpose involves constant adjustments to meet changes in the complex economic situation and to take into account an enormous spectrum

3 CRAIG, Paul. Administrative Law. 7. ed. London: Thomson, 2012, p. 568. ISBN 978-0-414-0229907; BRINKTRINE, Ralf. Verwaltungsermessen in Deutschland und England. Heidelberg: C. F. Müller, 1997, p. 379. ISBN 3-8114-8398-6.

4 BEBR, Gerhardt. Development of Judicial Control of the European Communities. The Hague-Boston-London: Martinus Nijhoff Publishers, 1981, p. 117. ISBN 978-90-24-7254-10.

5 Von DANWITZ, Thomas. Europäisches Verwaltungsrecht. Heidelberg: Springer, 2008, p. 370. ISBN 978-3540-79877-4; KLATT, Matthias a Johannes SCHMIDT. Spielräume im öffentlichen Recht: zur Abwägungslehre der Prinzipientheorie. Tübingen 2010, pp. 97-99. ISBN 978-3-16-150564-5. 
of divergent interests ${ }^{6}$. The judicial review of such an appraisal must therefore be limited to verifying whether the procedural rules have been complied with, whether the facts on which the contested choice is based have been accurately stated, and whether there has been a manifest error in the appraisal of those facts or a misuse of powers ${ }^{7}$. Pursuant to 263(2) TFEU, misuse of powers is one of the conditions for judicial review of the legality of legal acts adopted by EU bodies. As Gerhardt Bebr put it, this is the most radical and the most perplexing of all the grounds of illegality of an act ${ }^{8}$.

In a more general perspective, activities of the administration must be driven by its pursue of the general interest (French: intérêt général). Looking from a more detailed perspective: legal regulations assign particular objectives to specific powers ${ }^{9}$. Legal regulations may define the objectives of administration activities in a negative way: by ruling out their implementation (any act taken by an official to pursue his or her personal interest, intérêt personel, is defective), or in a positive way, by assigning specific objectives to specific powers. Any activity aimed at achieving an objective other than that specified in detail by the Act will be defective ${ }^{10}$.

Abuse of power in the classical approach involves the failure to comply with the above rules. It is a defect of an administrative act consisting in that the body exercised its competences to pursue an objective different from the one for which those powers were granted. In other words, misuse of power involves infringe the purpose of the powers granted to the body ${ }^{11}$.

6 European Court of Justice: 28 October 1982, 52/81, Faust, ECLI:EU:C:1982:369, \ 27; 5 October 1994, C-133/93, C-300/93 \& C-362/93, Crispoltoni, ECLI:EU:C:1994:364, J 57; 29 February 1996, C-296/93 \& C-307/93, French Republic and Ireland v Commission, ECLI:EU:C:1996:65, \59. Court of First Instance: 20 March 2001, T-52/99, T.Port, ECLI:EU:T:2001:97, \94; 10 February 2004, T-64/01 \& T-65/01, Afrikanische Frucht Compagnie, ECLI:EU:T:2004:37, \ 83-84.

7 European Court of Justice: 27 September 2007, C-351/04, Ikea Wholesale, ECLI:EU:C:2007:547, S 40, 41; 16 February 2012, C-191/09 P \& C-200/09 P, Commission v Interpipe Niko Tube and Interpipe NTRP, ECLI:EU:C:2009:454, \63; 4 September 2014, C-21/13, Simon, Evers \& Co GmbH v Hauptrollamt Hamburg-Hafen, ECLI:EU:C:2014:2154, \ 29.

8 BEBR, op. cit., p. 117.

9 DUBOUIS, Louis. La théorie de l'abus de droit et la jurisprudence administrative. Paris: LGDJ, 1962, p. 299; WALINE, Jean. Droit administratif. Paris: Dalloz, 2008, p. 606. ISBN 978-2-247-07913-1; GAUDEMET, Yves. Traité de droit administratif. Paris: L.G.D.J., 2001, p. 496. ISBN 978-2-275-02075-6.

10 DUPUIS, Georges, Marie-Jose GUÉDON a Patrice CHRÉTIEN. Droit administratif. Paris: Dalloz, 2009, pp. 494-495. ISBN 978-2-247-08059-5.

11 DUBOUIS, op. cit., pp. 29, 31; VIDAL, R. L'evolution du détournement de pouvoir dans la jurisprudence administrative. Revue de Droit Public, 1952, no. 2, p. 275; CHAPUS, René. Droit administratif général. Tome I. Paris: Motchrestien, 2001, p. 1048. ISBN 978-2-7076-1266-9; GAUDEMET, op. cit., p. 495; WALINE, op. cit., p. 606. Similarly in the Belgian law: BATSELÉ, Didier, Tony MORTIER and Martine SCARCEZ. Manuel de droit administratif. Bruxelles: Bruyllant, 2010, p. 851. ISBN 978-2-8027-2881-8; Dutch law SEERDEN, Rene and Fritz STROINK. Administrative law in the Netherlands. In: SEERDEN, Rene and Fritz STROINK. Administrative law of the European Union, its member states and the United States: a comparative analysis. Antwerpen: Intersentia, 2002, pp. 168-169. ISBN 90-5095-251-8); Spanish law (desviacion de poder) RETORTILLO BAQUER, Sebastian M. La desviación de poder en el derecho español. Revista de administración pública, 1957, no. 22, pp. 129-130; CLAVERO ARÉVALO, Manuel F. La desviación de poder en la reciente jurisprudencia del tribunal supremo. Revista de administración pública, 1959 no. 30, pp. 105-107; Italian law (sviamento di potere) CASSESE, Sabino. Istituzioni di diritto amministrativo. Milano: Giuffré Ed., 2004, p. 265. 
This comprises two groups of cases. The first one concerns the intention to achieve an objective out of the public interest, expressed in actions dictated by private motives (préoccupations d'ordre privê) ${ }^{12}$. The illegality of activities of the body, which fails to comply with the basic directive of acting in the public interest and is motivated by private motives, is manifest. French scholars of law provide a whole range of case law examples illustrating this type of abuse of powers: the mayor (mer) has dismissed the police officer who opened an investigation due to a violation of the provisions on the sale of alcoholic beverages against a shopkeeper who is a relative of mayor; the mayor has used his police competences to limit the operation of the dance hall that competes with his alcohol store; the authority has introduced a traffic ban in front of the private house in order to satisfy its owner; the mayor has issued an order to move the municipal marketplace to another place where merchants from other towns had limited parking options, the order was officially motivated to improve traffic, whereas in essence it was about the protection of local merchants, who bought permanent places in the marketplace; the cases of transfer to another post or dismissal of officials due to political motives; deliberate prolongation and interruption of the city council deliberations to delay the construction of the TGV rail section. ${ }^{13}$.

The second group of cases is more subtle. It comprises situations when the objective pursued by the public administration remains in the sphere of public interest, but it is not an objective assigned in the act to this powers. In other words, while issuing the act, the body acted in the public interest, but other than that which was supposed to be pursued pursuant to the law ${ }^{14}$. A specific example is the use of police and administrative powers not to enforce public order, but in the fiscal interest of the state or a municipality.

An illustration can be the classic judgements of the French Council of State (Conseild'Etat) of November 26, 1875, in cases Pariset and Laumonnier-Carriol, in which the Court has used the concept of détournement de pouvoir for the first time. The Act of August 2, 1872, made the expropriation of match factories, which became hence the subject of the monopoly of the state. The Act also provided compensation for expropriated entrepreneurs. To reduce the amount of these damages, the finance minister ordered the prefects to close some factories directly on the pretext that their activities are incompatible with the provisions on hazardous, arduous or polluting plants. The Council of State declared the prefects' orders invalid, considering that they had applied their police powers to achieve a goal other than that for which they were entrusted ${ }^{15}$.

12 CHAPUS, op. cit., p. 1049; DUPUIS, GUÉDON, CHRÉTIEN, op. cit., p. 655; LOMBARD, Martine and Gilles DUMONT. Droit administratif. Paris: Dalloz, 2007, p. 483. ISBN 978-2-247-07526-3; WALINE, op. cit., p. 606.

13 Cited in: CHAPUS, op. cit., p. 1049, WALINE, op. cit., p. 606.

14 DUBOUIS, op. cit., p. 31; WALINE, op. cit., p. 607; CHAPUS, op. cit., p. 1051; LOMBARD, DUMONT, op. cit., p. 483.

15 Cited in: WALINE, op. cit., p. 607; CHAPUS, op. cit., p. 1052. 
Similar ideas lay at the heart of the classic German concept of external and internal limits of discretionary powers. The external limits set the area beyond which the public administration remains closely bound by law. They are composed of norms defining powers, procedure and substantive legal conditions for action. Within this area, there are further limits delineated by objectives for which the freedom of action was granted to body. These boundaries define the permitted or forbidden motives for the action of the public administration. Accordingly, the body's error may consist in crossing the external borders, which is referred to as exceeding discretionary powers (Ermessensüberschreitung) or may involve crossing the internal borders, referred to as abuse of discretionary powers (Ermessensmißbrauch) ${ }^{16}$.

The evolution of judicial review of administrative discretionary powers was aimed at extending the scope of control by courts. Initially, it was considered that judicial review could only cover the excess of external borders, since discretionary acts (freies Ermessen) were not subject to judicial review ${ }^{17}$. With time it has been noticed, however, that statutory norms may not be violated also in the case of exercise of discretionary powers. As a result, the administrative court should review the compliance by the authority with both external and internal limits of the exercise of discretionary powers ${ }^{18}$. These classical considerations are reflected in contemporary regulations defining the administrative court jurisdiction in terms of verification of the legality of administrative activity ${ }^{19}$.

The key legal factor which determines the exercise of discretionary powers is the obligation to comply with the objectives of statutory authorisation. This is also related to the requirement to issue discretionary decisions on the basis of a factual point of view and after a comprehensive balancing of the public interest and individual interests ${ }^{20}$. This may be illustrated by the judgment of the German Bundesverwaltungsgericht of January 31, 1967, which indicated that in the case of a public assembly it would be an action deprived of substantive grounds, and hence unlawful, if the order to dissolve the assembly was dictated by the desire to prevent a public expression of a certain worldview or political views ${ }^{21}$.

16 Von LAUN, Rudolf. Das freie Ermessen. Lepizig-Wien: Deuticke, 1910, pp. 114-117.

17 Von LAUN, op. cit., pp. 219-220.

18 FLEINER, Fritz. Institutionen des Deutschen Verwaltungsrecht. Tübingen: J.C.B. Mohr, 1928, pp. $133-134$.

19 See: $\int 114.1$ German Code of Administrative Court Procedure (Verwaltungsgerichtsordnung, VwGO): "Soweit die Verwaltungsbehörde ermächtigt ist, nach ihrem Ermessen zu handeln, prüft das Gericht auch, ob der Verwaltungsakt oder die Ablehnung oder Unterlassung des Verwaltungsakts rechtswidrig ist, weil die gesetzlichen Grenzen des Ermessens überschritten sind oder von dem Ermessen in einer dem Zweck der Ermächtigung nicht entsprechenden Weise Gebrauch gemacht ist". See also: $\int 40$ of German Administrative Procedure Act (Verwaltungsverfahrensgesetæ, $V w V f G)$ of 25 May 1976: "Ist die Bebörde ermächtigt, nach ibrem Ermessen zu handeln, hat sie ihr Ermessen entsprechend dem Zweck der Ermächtigung auszü̈ben und die gesetzlichen Grenzen des Ermessens einzubalten”.

20 WOLFF, BACHOF, STOBER, op. cit., p. 377; RODE, op. cit., p. 89.

21 BVerwGE 26,135,140. 
In general terms, abuse of discretionary powers means an infringement of these requirements. The body abuses his powers when it pursues other objectives than those for which it has been granted discretionary powers, and it does not take into account the intentions of the lawmakers. The term of abuse also includes cases of non-legal (personal or political) motives that are not included in the criteria resulting from the objectives for which the body was granted discretionary power ${ }^{22}$. For example, as indicated by the Bundesverwaltungsgericht in the judgment of January 19, 2005, in the selection of persons who will be appointed for military service, the conscription bodies have discretionary powers. The bodies are guided primarily by public interest, expressed in the demand for conscripts, and not the private interest of persons subject to the obligation to serve. The person covered by the appointment may not defend himself with the argument that other persons subject to the obligation have not been appointed. However, a person subject to military service has the right to demand that the authority decide to put him into service in a manner free from arbitrariness, i.e. without following any irrelevant motives or intending to harm him. In this case, not only abuse of powers entrusted to the authority takes place, but also interference in the protected rights of the conscript. No citizen in the rule of law state can put up with the arbitrary decision of the authority deliberately aimed at violating his rights. In such situations, the citizen has the right to demand the repeal of this type of decision or its harmful effects ${ }^{23}$.

The classical English administrative law and case law have dealt with the problem of abuse of power in a similar way.

The conceptual category of abuse of discretionary powers in common-law culture terms is much more voluminous than in continental approaches. The key is not whether the body went beyond the boundaries delineated by the statutory authorisation. It is more the question, whether sovereign powers using by the body were not misused or insufficiently grounded. Thus, the court enters the area of review of the merits and substance of the decision and the grounds for $\mathrm{it}^{24}$.

The traditional basis of judicial review of administrative activities is the doctrine of ultra vires, which in brief means that a body is prohibited to act outside jurisdiction, which

22 MAURER, op. cit., pp. 149-150; RODE, op. cit., pp. 90-92, 99.

23 BVerwGE 122, 311, 315: "Der Webrpflichtige braucht aber nicht jede Auswablentscheidung der Bebörde obne die Möglichkeit der Gegenwehr hinzunehmen. Namentlich kann er verlangen, dass die Bebörde über seine Heranziehung oder Nichtheranziehung zum Webrdienst frei von Willkër, d.h. obne die Absicht entscheidet, ihn in sachwidriger Weise zu benachteiligen. In einem derartigen Fall liegt nicht nur ein Missbrauch des der Bebörde eingeräumten Ermessens und damit eine Verletzung von objektivem Recht, sondern darüber hinaus auch ein Übergriff in die verfassungsrechtlich geschütz̨te Individualrechtssphäre des Wehrpflichtigen vor, die dieser abzuwehren berechtigt ist. Denn kein Bürger braucht im Rechtsstaat eine ihn gezielt benachteiligende Willkürentscheidung der Behörde zu dulden; vielmehr kann er unter Berufung auf das jeweils berührte Grundrecht die Aufhebung dieser Entscheidung oder ibrer benachteiligenden Wirkungen erreichen".

24 Por. WOOLF, JOWELL, LE SUEUR, op. cit., p. 544. 
is the key feature of the entire administrative law. Exceeding the limits of the powers by the administrative body may be expressed in three classic forms: excess of power, abuse of power and violation of procedural rules ${ }^{25}$.

The concept of ultra vires is based on the assumption that the legislature grants discretionary powers with a certain objective to be pursued. Using discretionary powers in a way inconsistent with the will of the legislature is an unlawful act ${ }^{26}$. In other words, the authority exceeds its powers when it does not comply with the limits of the discretion margin granted to it, referred to expressis verbis or implicitly in the statutory authorisation.

The most characteristic weaknesses as to the purpose are cases in which the body acted for political reasons, which have no connection with the legal fundament of the competence. An example is the case R. v. Ealing London Borough Council, ex parte Times Newspaper Group of $1987^{27}$. According to the Public Libraries and Museums Act of 1964, the Ealing district council in London was committed to providing a comprehensive and effective library service to all interested users. In implementing this broad and quite vaguely defined obligation, which gives the body a wide sphere of decision-making flexibility, the body should also take into account the needs of users. When there was a longstanding labor dispute between the Times publishing group and trade unions, dominated by the labor party members, the Council decided to remove all magazines of this publishing group from the offer of the library as part of solidarity with the strikers. The Times group questioned effectively this "excommunication" before the court. The Court considered that the decision of the Council was motivated by the desire to support the workers' fight against the tyranny of the employer and to punish the latter for his actions by excluding from the offer his magazines. In this way, the Council interfered in the labor dispute, and this political motif has nothing to do with the purpose of the provisions of the Public Libraries Act, which constitute a source of power to act under discretionary powers.

Another example of the use of discretionary powers to achieve a wrong purpose may be the Magill v. Porter case ${ }^{28}$, in which the conservative leaders of the Westminster City Council used their powers to make decisions in the field of municipal housing economy, to increase the number of apartments for persons under court guardianship to encourage them to vote for the conservative party in future elections. The District Auditor questioned the legality of these activities, and the House of Lords upheld his decision. The Lords indicated that although the Council's competence in the field of using municipal real estate is very wide and although elected politicians are entitled to act in a way

25 WADE, William and Christopher FORSYTH. Administrative Law. 9. ed. New York: Oxford University Press, 2004, pp. 35-36. ISBN 0-19-926995-5.

26 CRAIG, 2012, op. cit., p. 5.

27 High Court (Queens Bench Division): 6 November 1987; (1987) 85 L.G.R. 316.

28 House of Lords: 13 December 2001; [2001] UKHL 67. 
that can be supported by the electorate, they can only act to achieve public goals for which they have been entrusted with the imperative powers. Powers conferred on a local authority may not lawfully be exercised to promote the electoral advantage of a political party.

In the case R. v. Lewisham London Borough Council, ex parte Shell U.K. Ltd. ${ }^{29}$, the London City Council, pursuing its generally defined obligation to improve relations between the communities inhabiting the commune, resulting from the Race Relations Act of 1976, decided not to buy Shell products. The boycott was meant to influence the global concern to end its economic activity in South Africa (due to the apartheid issue in the country). The court repealed the act, stressing that maintaining trade relations with South Africa is not illegal, so an attempt to influence the concern by boycotting its products meant striving to achieve an unlawful goal.

Courts derive the non-defined limits of administrative powers from certain basic standards of using discretionary powers. The discretionary powers should be exercised reasonably and in good faith, only the relevant factors in the case should be taken into account, it is unacceptable to compromise in any way entrusted functions, the decision cannot be arbitrary or constitute a caprice of the authorities ${ }^{30}$.

One of examples of arbitrary criteria used by the body is the decision in the Wheeler v. Leicester City Council case ${ }^{31}$, where the municipality refused to provide the rugby club with communal sports facilities for the reason that the club members did not support the political position represented by the majority in the municipal council, which was expressed in taking part in the rugby competition in South Africa during the apartheid period.

Another example is the case of R. v. Port Talbot Borough Council, ex parte Jones ${ }^{32}$, in which the decision to postpone the request for granting social housing from urban resources by giving priority to an application at the bottom of the list, was considered unlawful, because it was supported by arbitrary criteria. The motivation for changing the order of applications was the intention of the decision maker to increase their chances in the upcoming elections by supporting certain people.

29 High Court (Queens Bench Division): 21 October 1987; [1988] 1 All E.R. 938.

30 WADE, FORSYTH, op. cit., p. 350. See also a statement by Lord Denning in Case Breen v. Amalgamated Engineering Union: "The discretion of a statutory body is never unfettered. It is a discretion which is to be exercised according to law. That means at least this: the statutory body must be guided by relevant cosiderations and not by irrelevant. If its decision is influenced by extraneous cosiderations which it ought not to have taken into account, then the decision cannot stand. No matter that the statutory body may bave acted in good faith; nevertheless the desion will be sey aside" (Ibid., p. 358).

31 House of Lords: 25 July 1985, [1985] UKHL 6.

32 High Court (Queens Bench Division): 2 January 1988; ([1988] 2 All E.R. 207 (214). 
The concepts developed under national legal systems have influenced to the premises of abuse of power in the EU courts case law in view of Article 263(2) TFEU and earlier treaty regulations indicating the conditions for the annulment of an act of an EU institution $^{33}$. According to the general definition developed in the case-law, abuse of powers occurs when it can be stated on the basis of objective, relevant and consistent factors that the act was adopted by the EU institution with the exclusive purpose, or at any rate the main purpose, of achieving an end other than that stated or evading a procedure specifically prescribed by the Treaty for dealing with the circumstances of the case ${ }^{34}$.

\section{Abuse of discretionary powers and "administrative morality"}

The concept of abuse of right is strongly characterised by axiology. It is connected with the negative assessment of the entity using a right in a manner inconsistent with commonly accepted social values that form the basis for the axiology of the entire legal system. Abuse of right means an action that is negatively assessed not only in the legal perspective but also in the moral perspective.

As I have already mentioned, the classical approach of the concept of abuse of discretionary powers involves subjective evaluation criteria referring to the mental states of an official, i.e. bad faith or personal motives.

33 BEBR, op. cit., p. 117; CRAIG, Paul. EU Administrative Law. New York: Oxford University Press, 2006, p. 462. ISBN 978-0-19-929680-4; TOTH, Alexander. The Oxford Encyclopedia of European Community Law. Oxford 2005, pp. 368-369. ISBN 978-01-98256-007; CLEVER, Friedrich. Ermessensmi $3 b r a u c h$ und détournement de pouvoir nach dem Recht des Europäischen Gemeinschaften im Licht der Rechtsprecbung ibres Gerichtshofes. Berlin: Duncker \& Humblot, 1967, pp. 15-17.

34 European Court of Justice: 21 December 1954, 1/54, French Republic v High Authority of the European Coal and Steel Community, ECLI:EU:C:1954:7; 4 February 1982, 817/79, Buyl and Others v Commission, ECLI:EU:C:1982:36, \ 28; 13 November 1990, C-331/88, Fedesa, ECLI:EU:C:1990:391 \ 24; 12 November 1996, C-84/94, United Kingdom v Council, ECLI:EU:C:1996:431, 『 69; 25 June 1997, C-285/94, Italy v Commission, ECLI:EU:C:1997:313, \52; 5 Mai 1998, C-180/96, United Kingdom $v$ Commission, ECLI:EU:C:1998:192, \52; 14 Mai 1998, C-48/96 P, Windpark Groothusen v Commission, ECLI:EU:C:1998:223, \52; 22 November 2001, C-110/97, Netherlands v Council, ECLI:EU:C:2001:620, \137; 10 Mai 2005, C-400/99, Italy v Commission, ECLI:EU:C:2005:275, \38; 10 March 2005, C-342/03, Spain v Council, ECLI:EU:C:2005:151, \ 64; 7 September 2006, C-310/04, Spain v Council, ECLI:EU:C:2006:521, \ 69. Court of First Instance: 6 April 1995, T-143/89, Ferriere Nord v Commission, ECLI:EU:T:1995:64, pkt 68; 14. 11. 2002, T-332/00 i T-350/00, Rica Foods \& Free Trade Foods v Commission, ECLI:EU:T:2002:274, \200.

TOTH, op. cit., p. 369; CRAIG, Paul and Gráinne de BÚRCA. EU Law. Text, Cases and Materials. Oxford: Oxford University Press, 2003, p. 536. ISBN 0-19-924943-1; LÉGER, Paul. Commentaire article par article des traités UE et CE. Bâle-Genève-Münich: Helbig \& Lichtenhahn, 2000, p. 700. ISBN 3-7190-1815-6; Van RAEPENBUSCH, Sean. Droit institutionnel de l'Union et des Communautés européennes. Bruxelles: Larcier, 2001, p. 509. ISBN 978-2-8044-7818-6; SCHERMERS, Henry. Judicial Protection in the European Communities. The Hague: Kluwer Law Int., 2001, p. 191. ISBN 90-411-16311. 
In the first half of the twentieth century the concept of détournement de pouvoir was at the peak of its "popularity". At that time Maurice Hauriou ${ }^{35}$ and Henri Welter ${ }^{36}$ claimed that this is a key element of control of administrative morality of administration (moralité administratiff. This concept assumed that judicial review did not only concern the formal compliance of administrative activities with the law, but also was intended to serve the interest of good administration (l'intérêt d'une bonne administration), that is one that respects the rights of individuals and effectively performs public service tasks.

The concept of "administrative morality" changed the significance of the criteria to assess activities of the administration. It is difficult to consider such concepts in pure categories of compliance with the law. "Administrative morality" refers rather to administrative deontology and the reasonableness of activities of the body. If an official uses his powers for private purposes or for other purposes contrary to the public interest, he abuses the functions entrusted to him. Such behaviour deserves not only to be morally deplored but has also legal consequences. Therefore, the negative assessment of the official's action must also be reflected in the judgement of the administrative court, which should repeal an act that violates the requirements of "administrative morality" 37 . Similar elements can be seen in classical English administrative law, where "bad faith" is listed as a traditional basis for repealing the act because of abuse of discretionary powers. In the strict sense, this includes cases of deliberate abuse of discretion, as opposed to a situation where the body misuses discretion, but does it as a result of ignorance or misunderstanding of the intent of the legislature. To be classified as bad faith, the deed concerned must be an intentional dishonest action. This includes intentional damage, fraudulent manipulation, dishonesty, malice and other deliberate infringements $^{38}$. Typical symptoms of bad faith are cases of deliberate favouritism or dismissal of claims of applicants due to personal liking or antipathy. There are also detrimental activities motivated by the desire for revenge.

An example of this may be the judgement in the case R. v. Derbyshire County Council, ex parte The Times Supplements Limited ${ }^{39}$, issued on the basis of the following facts: after The Sunday Times published numerous critical articles about influential members of local educational authorities, the educational administration authority decided to publish job vacancies for teachers not in the educational supplement of The Times, but in Guardian, despite The Times had a much wider distribution range and so far there were no objections to cooperation. Because the body could not determine the basis for its decision,

35 As expressed in his classic coursebook: Droit administratif. Paris, 1897.

36 WELTER, Henri. Le côntrole juridictionnel de la moralité administrative. Paris: Sirey, 1929, passim.

37 DUBOUIS, op. cit., pp. 192-193.

38 CRAIG, 2012, op. cit., p. 576; BRINKTRINE, op. cit., pp. 399-400; WOOLF, JOWELL, Le SUEUR, op. cit., pp. 266-267; WADE, FORSYTH, op. cit., p. 416.

39 High Court (Queens Bench Division): 18 July 1990, [1991] 3 Admin. L.R. 241. 
which would indicate a reference to the field of education or provide other convincing arguments for its decision, the court concluded that the change for another newspaper was caused only by bad faith, a desire for personal revenge, punishing the journal publisher for critical publications.

„Administrative morality" as a criterion of review induces the search for subjective, underlying intentions of an official: bad faith, personal animosities, private motives. The result is difficulties in the practical application of the concept of abuse of power.

Intentions of an official who issues an administrative act form the psychological element, which is difficult to detect. The only exception is when the author expresses his intentions openly, but this is of course rare for administrative acts ${ }^{40}$. In this situation, difficulties with evidence finding are inevitable, especially considering the general principle that the complainant bears the burden of proof as to the unlawfulness of the $\mathrm{act}^{41}$.

The difficulties with evidence finding become even deeper if we take into account the specific manner of activity of the public administration. It is a mechanism whose individual cogs are virtually unnoticeable to an external observer. The specific character of such organism as the public administration hinders the search for subjective motivations related to the activities of specific officials.

The very criterion of administrative morality was not very transparent also. It forced the reference to criteria not expressed directly in normative acts, and in addition it meant constant balancing at the limits of what was allowed and what was forbidden. Abuse of power rarely concerned cases of manifest, apparent bad will and motivation deserving not only moral but also legal reproach. Most of judgements were issued in borderline and open situations, providing the possibility of different assessment.

As a result, while applicants often raised the allegation of abuse of power, the number of judgements in which administrative courts reached for this instrument have decreased significantly with time. This process induced some authors to express the opinion of decline (déclin) or marginalisation of détournement de pouvoir ${ }^{42}$.

40 GROS, Manuel. Fonctions manifestes et latentes du détournement de pouvoir. Revue de Droit Public, 1997, no. 9-10, pp. 1238-1239; LEMASURIER, Jean. La prevue dans le détournement de pouvoir. Revue de Droit Public, 1959, no. 1, pp. 59-60.

41 Conseil d'Etat: 26 January 1968, Societé "Maison Génestal”, as cited in: LACHAUME, Jean-François and Hélène PAULIAT. Droit administratif (Les grandes decisions de la jurisprudence). Paris, 2007, pp. 744-745. ISBN 978-213-0556503.

42 De FORGES, op. cit., p. 279; FERNANDEZ-MAUBLANC, Lucienne-Victoire. Le prétendu déclin du détournement de pouvoir. In: Mélanges offerts à Jean-Marie Auby. Paris: Dalloz, 1992, p. 239. ISBN 978-22470-1353-1. The Belgian administrative law's literature provides similar reasons for the very rare use of the power abuse concept by the Belgian Council of State (BATSELÉ, MORTIER, SCARCEZ, op. cit., p. 851). 


\section{Evolution of classic concepts of abuse of discretionary powers in case law and scholarly opinion.}

\subsection{Difficulties in evidence finding and the objectivity of assessment criteria}

The classic approach to the abuse of discretionary powers, which stressed the need to discover the actual intentions and bad faith of the official concerned, significantly weakened the practical effectiveness of this construct as a means of judicial review of public administration. Attempts to solve this problem went in various directions.

On the one hand, there has been a tendency to objectify the criteria for assessing the functioning of the body under the concept of abuse.

One of the flaws of the classic approach to abuse of power was difficulties with evidence finding. The complainant bringing the claim to court had to demonstrate the official's negative intentions. The presumption of abuse of power was definitely ruled out ${ }^{43}$. Due to the aforementioned specificity of administrative activities, which "is revealed" to the individual only in the form of an administrative act, it could be impossible to prove bad faith or negative personal motives of the official.

The case law has evolved towards a gradual loosening of the evidence requirements ${ }^{44}$. Despite the complainant-friendly tendency in the settled case law, abuse of power is difficult to prove. Administrative courts work on material in the form of documents, they are not willing to conduct a meticulous "investigation" on their own to discover actual motives of the officials. Testimonies given by officials at hearings have a weak evidential value because they, as representatives of the party to the dispute, can only be subject to an information hearing and not a hearing as witnesses ${ }^{45}$.

Similar tendencies are also seen in the EU case law. The jurisprudence assumes that the EU institutions apply a kind of "presumption of innocence". It is assumed that by undertaking actions they aimed at achieving legitimate goals unless it is proven otherwise. As a result, it is the appellant's role to provide objective evidence that the EU institution has misused its powers. Intentions and motives behind actions taken by EU institutions require proof, which is difficult to provide, in particular for private entities that may not have access to the relevant documents. The ECJ takes into account the allegation of abuse of power only when there are objective, relevant and consistent indications that the act was adopted to pursue an end other than that which should be lawfully pursued $^{46}$.

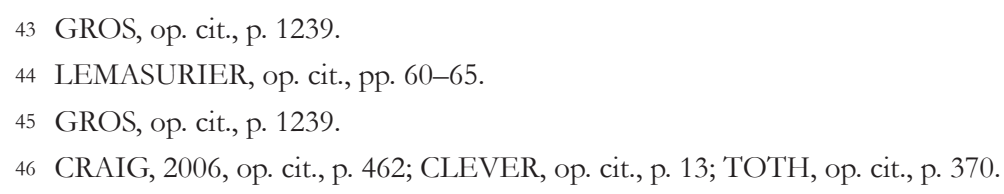


To determine that there was an abuse of power in the case one needs first to discover the real intentions of the institution, that is, the objectives it pursued by undertaking the act in question. It is then necessary to demonstrate that this objective differs from that which the institution should or could have legitimately pursue in the circumstances in which it acted. In this respect, the evolution of the EU courts' approach towards objectivity of criterion is noticeable. Originally, it was assumed that the only criterion for the examination is the intention of the administrative body. In the meantime, there has been a reorientation towards the objective properties of the act: an abuse of powers occurs when, from an objective point of view, the action aims at pursuing an unacceptable objective. The acceptable objective should be extracted from the authorizing norm on which the contested act was based, and from the general objectives of the Treaty ${ }^{47}$.

\subsection{Displacement of abuse of discretion by other grounds for the review of discretionary powers of the administration}

The second direction of the evolution of scholarly and jurisprudential views led to the phenomenon of a gradual displacement of the concept of abuse of power by other grounds for judicial review, which allow achieving the same effect in the form of repealing the act, and are based on more transparent criteria.

An example of this process may be matters regarding the so-called nomination for the order (nominations pour ordre), i.e. appointment to positions in public administration (usually high-level), which do not entail actual performance of the function, but only benefits related to the position. A classic example is the Council's of State judgment of January 8, 1971, in the case Association des magistrates et anciens magistrates de la Cour de Comptes ${ }^{48}$ : the Council annulled the nomination act, considering it invalid and irrelevant, as it was demonstrated that the nomination procedure was not related to the existence of a real vacancy, the nominated person never performed the functions entrusted to him, and the only goal was, on the one hand, to obtain the benefits envisaged by the law related to the nomination, on the other, to open the path to another post to which the appointed person aspired. Another example, can be the judgement mentioned in the French media: Judgement of Council of State of 18 January 2013, regarding the appointment to the position of Advocate General (avocat général) in the Court of Cassation (Cour de Cassation) of a person who at the time of nomination was the director of the office of the Minister of Justice and remained in that position despite the nomination, and therefore could not, and in fact did not perform the new function to which had been appointed ${ }^{49}$.

47 CRAIG, 2006, op. cit., p. 463; Van RAEPENBUSCH, op. cit., p. 509; VOCKE, Christian. Die Ermittlungsbefugnisse der EG-Kommission im kartellrechtlichen Voruntersuchungsverfahren. Berlin: BWV Verlag, 2006, p. 53 ISBN 978-38-305-1228-8; von DANWITZ, op. cit., p. 369.

48 Recueil Dalloz 1971, p. 26.

49 Available from: http://www.conseil-etat.fr/fr/base-de-jurisprudence/; case no. 354218. 
This is an obvious use of powers contrary to their purpose, which indicates the construct of détournement de pouvoir. However, administrative courts prefer to use another measure, more reliable and easier for evidentiary reasons, namely to declare the act non-existent (inexistence juridique) that is to declare it null and void (nul et non avenues, de nul effet) ${ }^{50}$.

An instrument used by the courts for this purpose are the general principles of law, e.g. the principle of equality. An example is the Council's of State judgment of Mai 29, 1954, in Barel case ${ }^{51}$ : the complainant was removed from the list of competition candidates to the École nationale d'administration because of the communist views he presented. The use of competences in the selection of candidates for school to remove a person whose political views the decision maker does not accept could be successfully classified as an abuse of power. However, the Council did not use this argument but referred to the violation of the principle of equality, claiming that the equality of all French people in access to public offices does not allow the deletion of a candidate from the list only on the basis of his political views.

A similar case, in which the concept of abuse of power was replaced by the violation of the principle of equality is the judgment of the Council of State of 30 June, 1989 in the case Ville de Paris c. Levy ${ }^{52}$. In the case, the court questioned the legality of the resolution of the Conseil de Paris to the extent introducing the conditions of nationality in the granting of certain benefits in the field of municipal assistance. Since the reason of action was in fact the concern for the protection of demographic balance in Paris, this could justify the charge of abuse of power, because these are not goals and reasons that can be implemented by actions in the area of social welfare. However, the administrative courts expressly preferred to find a violation of the principle of equality in this case by differentiating between Parisians of French and non-French nationalities.

Another example is the displacement of classical concepts of abuse of discretion by the principle of proportionality, having a similar structure, giving similar effects, but considered to be more transparent in application. Separate points will be provided hereinafter on this question.

\subsection{Abuse of power in other areas of discretionary power of the administration}

The third direction of the evolution of views in the area of judicial review of discretionary powers of public administration resulted from the need to "complete" this review in a slightly different aspect. The risk of the administration evading charges of abuse of power in a completely different direction was observed.

\footnotetext{
50 Por. GROS, op. cit., p. 1245.

51 The review of the judgment is available from: http://www.conseil-etat.fr

52 Available from:http://www.legifrance.gouv.fr/affichJuriAdmin.do?idTexte=CETATEXT000007754407
} 
Judicial review covers only the legality of an administrative act, its compliance with legal rules that determine the work of the administration. If such a legal rule allows the administrative body to act freely, the body decides based on opportunity (opportunité). The administrative court does not review opportunity ${ }^{53}$.

As Georges Vedel notes, if the administration operates within circumscribed powers, its activities can be assessed in terms of their legality. The public administration can only decide to the extent allowed by law. Its act may, therefore, be compliant or non-compliant with law. On the other hand, if the administration has discretionary powers, its act can only be judged in terms of reasonableness: the act may be opportune or not opportune, right or wrong, but it cannot be illegal until the administration has the freedom to $\operatorname{act}^{54}$.

Since the legislator grants the body freedom to assess, the court cannot examine it, because there are no criteria for assessing what are the rules determining the way the body acts. Consistently following this argument, it would entail allowing any arbitrariness of the administration, and thus the possibility of abuse the body's discretion in the area of assessing the factual basis of the decision.

Therefore, constructs have been developed to prevent leaving the discretionary sphere of administration activities out of the scope of judicial review. These include the concept of manifest error in assessment (erreur manifeste d'appréciation), balance control and the principle of proportionality, which will be discussed further in this paper.

As Judge of the Council of State Guy Braibant ${ }^{55}$, pointed out, the construct of manifest error in assessment is aimed at limiting abuses that may occur during exercise of discretionary powers. For this reason, it is similar to the construct of détournement de pouvoir. The purpose of the prohibition of abuse of power is to subject the public administration to minimum standards of morality and prevent the use of powers to pursue objectives inconsistent with the public interest. Similarly, the criterion of manifest error in assessment is to instruct administrative bodies to adhere to logic and common sense. Even where authorities have the powers to do what they think is right, they are not authorised to do anything (Même lorqu'elles ont le pouvoir de faire ce qu'elle veulent, elles ne doivent pas être autorisées à faire n'importe quoi).

The notion of manifest error in assessment is specific, it contains a certain charge of subjectivity. Scholars describe it as an obvious error, which does not raise any doubt for a reasonable person (esprit éclairé), a serious, grave (grossiere), flagrant error. This refers

53 SERRAND, Pierre. Le contrôle juridictionnel du pouvoir discrétionnaire de l'administration à travers la jurisprudence récente. Revue du droit public, 2012, no. 4, p. 906.

54 VEDEL, Georges and Pierre DELVOLVÉ. Droit adminitstratif, T. 1. Paris: Presses Universitaires de France, 1992, p. 529. ISBN 978-213-04506-58.

55 In the commentary on the Council of State's judgement in case Lambert of 13 November 1970 (Actualite Juridique: Droit Administratif, 1971, p. 35), as cited in: SERRAND, op. cit., p. 907. 
to a resolution that exceeds all norms of rationality, an error which does not result from discretion but from arbitrariness (non pas discrétionnaire mais arbitraire) ${ }^{56}$.

An example may be the judgement of the Council of State of December 16, 1988 in the Bléton case $^{57}$, which involved appointing a person who did not have any professional experience or knowledge to take up such a position as a general inspector of libraries. The Council stated that the regulations on the basis of which the nomination was made contained only the age requirement, thus leaving the government a very wide margin of discretion, however they did not exempt from the obligation to comply with the basic principle expressed in Article 6 of the Declaration of Human Rights, according to which all the citizens have equal access to all public dignities, positions and functions, depending on their aptitudes and with only the differences that arise from their virtues and talents (selon leur capacité et sans autre distinction que celle de leurs vertus et de leurs talents). The assessment of candidate's capacity for a function should take into account the scope of tasks related to this function, indicating the need to have appropriate knowledge and professional experience. The circumstances of the case indicated, that the minister would like to "reward" his colleague, so the facts in the case indicated that there had been abuse of discretionary powers because the minister has misused his powers. Nevertheless, the Council repealed the act because of a manifest error of appreciation, without referring at all to the abuse of powers.

The concept of manifest error developed in the EU courts case law is of similar character. Its source is the historical Article 33.1 of the ECSC Treaty, which is a kind of counterpart of the current Article 263.2 TFEU ${ }^{58}$. The term "clearly misinterpreted the provisions of the Treaty" used in that provision was interpreted in the ECJ case law as a significant misinterpretation or misapplication of the provisions of the Treaty resulting from a manifest error in assessment of the economic situation in the light of the circumstances in which the act under review was issued. The ground of manifest error was to make it possible for the Court to review the Commission's assessment of the situation in which it issued the contested act, to examine whether the act was manifestly unfounded ${ }^{59}$.

56 CHAPUS, op. cit., p. 1066; GAUDEMET, op. cit., p. 502; GROS, op. cit., p. 1250; SERRAND, op. cit., pp. 907-908.

57 Cited by: GROS, op. cit., p. 1250.

58 According to this provision, the Court shall have jurisdiction over appeals by a member State or by the Council for the annulment of decisions and recommendations of the High Authority on the grounds of lack of legal competence, substantial procedural violations, violation of the Treaty or of any rule of law relating to its application, or abuse of power. However, the Court may not review the conclusions of the High Authority, drawn from economic facts and circumstances, which formed the basis of such decisions or recommendations, except where the High Authority is alleged to have abused its powers or to have clearly misinterpreted the provisions of the Treaty or of a rule of law relating to its application.

59 TOTH, op. cit., p. 368. 
The concept of manifest error has been confirmed in the jurisprudence of ECJ under the EEC Treaty (now TFEU). The ECJ assumes that where an EU institution is granted significant discretion to assess economic conditions in which it formulates or applies economic policy measures, the courts, when examining the lawfulness of the exercise of such freedom, cannot substitute their own evaluation of the matter for that of the competent authority. In such cases, they must restrict themselves to examining whether the evaluation of the competent authority contains a patent error or constitutes a misuse of power ${ }^{60}$.

The classic English doctrine of irrationality plays a similar role. In a strict, substantive sense, according to Lord Green's classic approach, a decision is irrational when it is so absurd "(...) that no sensible person could ever dream that it lay within the powers of the authority" ". In the later formulation of this approach by Lord Diplock, a decision can be described as irrational, when is "(...) so outrageous in its defiance of logic or of accepted moral standards that no sensible person who had applied his mind to the question to be decided could have derived at it" ${ }^{62}$. In this sense, the irrationality test describes the outermost, final limit of discretionary powers, the authority is not allowed to exceed ${ }^{63}$. The jurisprudence holds the view that the decision is "irrational" when it is "perverse" 64 " "manifestly absurdly" or "So wrong that no reasonable person could sensibly take that view" porary approaches, the criterion of rationality of the exercise of discretionary powers includes examining whether the decision falls within the range of reasonable resolutions that may be chosen by the author of the decision ${ }^{67}$.

60 European Court of Justice: 14 March 1973, 57/72, Westzucker v Einfuhr- und Vorratsstelle für Zucker; ECLI:EU:C:1973:30, \14. Similarly ECJ in Judgement of 25 January 1979 (98/78, A. Racke v Hauptrollamt Mainz, ECLI:EU:C:1979:14, \5): "[...] since the evaluation of a complex economic situation is involved, the Commission enjoy, in this respect, a wide measure of discretion. In reviewing the legality of the exercise of such discretion, the Court must examine whether it contains a manifest error or constitutes a misuse of power or whether the authority did not clearly exceed the bounds of its discretion".

61 Court of Appeal: 10 November 1947, Associated Provincial Picture Houses Ltd. v. Wednesbury Corporation, [1948] $1 \mathrm{~KB} 223$.

62 Lord Diplock in: House of Lords: 22 November 1984, Council of Civil Service Unions v. Minister for the Civil Service, [1985] 1 AC 374.

63 CRAIG, 2012, op. cit., p. 562; BRINKTRINE, op. cit., p. 393.

64 Lord Ackner in: House of Lords: 7 February 1991, R. v. Secretary of State for the Home Department, exparte Brind, [1991] 1 AC 696.

65 Lord Bridge of Harwich in: Court of Appeal: 4 October 1990, Secretary of State for the Environment, exparte Hammersmith and Fulham London Borough Council; 3 All E.R. 589 (614).

66 Lord Denning in: House of Lords: 21 October 1976, Secretary of State for Education and Science v. Tameside Metropolitan Borough Council, [1977] AC 1014.

67 WOOLF, JOWELL, Le SUEUR, op. cit., p. 545; CRAIG, 2012, op. cit., p. 563. 


\section{Abuse of power and proportionality}

As mentioned above, the effect of displacement of the classic concept of abuse of powers by the principle of proportionality can be noticed in the administrative courts' case law regarding the judicial review of discretionary powers.

The European legal culture employs a three-element formula of proportionality, which stemmed from the German case law and constitutional doctrine (Grundsatz der Verbältnissmäßigkeit ${ }^{68}$, and these elements are: suitability, necessity and proportionality in a strict sense. Suitability means that measures that actually serve to pursue the objective should be chosen. Necessity means choosing the measure that least interferes with the legally protected sphere of an individual, but allows to achieve fully the intended objective. Proportionality in a strict sense is the balancing of goods and interests, the need to prove that under the circumstances of the case the public interest is more valuable than the private interest.

There are two „converging points” between the principle of proportionality and the concept of abuse of power.

The first concerns the element of suitability. The relationship between the measure and the goal in administrative law is special. Any power granted to the authority, especially one that grants the possibility of interference, has its purpose, it is an instrument for the implementation of specific administrative tasks. The administration may not freely set objectives of its action and to select applicable measures. A measure is usually associated with a specific goal, especially if it is of a strictly imperative nature.

Abuse of powers consists precisely in the use of powers (ergo: the measure) for the purpose not provided for by the legislature. This problem can also be approached in terms of the principle of proportionality: a measure used to achieve an objective not provided for by the legislature does not meet the criterion of suitability. The difference lies in the perspective taken. The concept of abuse of powers does not undermine the fitness of the measure to achieve the objective intended by the authority. It questions the goal itself in the sense that such link between the measure and the objective intended by the authority is not permitted by law. The law binds the powers with a specific objective. If the objectives falls outside the scope of the powers, this undermines the legality of all the measures applied. Therefore, it can be said that the concept of abuse of powers questions the authority's action closer to the „core of the powers" than the principle of proportionality, which focuses more on the relationship between the methods used and the objectives pursued. The concept of abuse of powers challenges not only the measure, but also the objective chosen by the authority, as an objective not legally related to the powers concerned.

68 See the fundamental analysis of the problem by STEPKOWSKI, Aleksander. Zasada proporcjonalności w europejskiej kulturze prawnej. Warszawa: Liber, 2010, pp. 189-209. ISBN 978-83-72061676. 
An example is the classic judgement of the French Council of State of May 19, 1933, in the Benjamin case ${ }^{69}$. The Council formulated a very important principle, which was later repeatedly invoked: in the sphere of freedom of assembly, freedom is the rule while the police restriction is an exception (la libertéest la règle, la restriction de police l'exception). The case concerned a complaint against holding a public conference. The mayor made such a decision due to numerous protests by teachers' trade unions, accusing the organizer of radical criticism of the education system on the occasion of such meetings. The Council repealed the ban on the assembly, arguing that the threat of public disorder invoked by the mayor was not serious enough to justify a ban on the organization of the assembly, guaranteed by law. The Council referred to the principle of proportionality, although with another approach in the case it was possible to apply the construction of the prohibition of abuse of rights. The reason for banning the assembly by the mayor was essentially to take into account the demands of teachers accusing the organizers of denouncing the educational system, not the threat to public order. The mayor used therefore his competence in the field of administrative police for a purpose other than provided for by the legislator, and this is a classic abuse of powers.

In brief: in the case of abuse of powers, the intended objective of the act is itself unlawful (an objective which is different from the one for which the authority was granted the powers) while pursuing a right objective using wrong means is subject to the review of proportionality ${ }^{70}$.

The second surface of contact is already less precise, it concerns the „,core of proportionality", which is the balancing of values and interests. Especially in more general formulas of abuse of powers (such as in the English concepts), references arise as to axiological shortcomings, failure to take into account all relevant circumstances and the lack of their proper balance. In more precise concepts, these issues do not fall within the concept of abuse of discretion, but rather they are classified as errors resulting from a breach of the margin of appreciation (marge d'appréciation). However, if a more general formula is adopted, the criteria of abuse of powers and proportionality overlap.

Above mentioned certain marginalization of the traditional concept of abuse of powers is evident with respect to the classical French construct of détournement de pouvoir, and the effect of displacement of the classic concept abuse of power by the principle of proportionality is also noticeable in the judicial review of acts of EU institutions.

As explained above, this results from the difficulty in demonstrating the evidence for abuse of power, resulting in that this charge is rarely admitted by the EU courts. This creates a kind of feedback: the difficulties make the complainants to choose other

69 Available from: http://www.conseil-etat.fr/Decisions-Avis-Publications/Decisions/Les-decisions-les -plus-importantes-du-Conseil-d-Etat/19-mai-1933-Benjamin

70 Similarly: CRAIG, de BURCÁ, op. cit., pp. 536-537; EMILIOU, Nicholas. The Principle of Proportionality in European Law. London: Kluwer Law Int., 1996, p. 191. ISBN 978-9041108661. 
charges, in particular violation of proportionality, and this results in a smaller number of cases in which the charge of abuse of power was considered by the court at all. Another reason for diminishing the practical role of the concept of abuse of power is also the fact that this ground of complaint requires an in-depth review of the legality of action of the body, because it deals with a situation of particularly deeply underlying irregularities. For this reason, the analysis of this error usually appears at the end of the judge's reasoning, who rather decides to annul the act based on other grounds. This leads to the gradual displacement of the criterion of abuse of power by other review criteria, including proportionality ${ }^{71}$. As a result, the charge of abuse of power loses its independent character, becoming in fact a rhetorical element used in a complaint or grounds of the judgement, rather than a separate legal construct ${ }^{72}$.

Some authors, therefore, claim that in the review of discretionary powers of EU bodies, the EU courts case-law has evolved from abuse of power to the protection of fundamental rights and respectively the principle of proportionality related ${ }^{73}$.

A likewise phenomenon is seen in the English model of judicial review of discretionary powers. Despite the initial restraint by the judiciary, the principle of proportionality became, with time, one of cornerstones of the review of discretionary power of public administration. Some authors claim that the increase in the significance of the proportionality criterion may lead to eradication of the classical doctrine of irrationality ${ }^{74}$. However, this does not mean a transition to the merits review, but rather a stress on the "culture of justification" that obliges the author of the decision to consider the relation between measures and objectives. Courts require a more elaborate substantiation of the decision, but the merits of the decision will remain within the responsibility of the original author of the decision (administrative body). The responsibility of the author of the decision will be to indicate the factors taken into account and to explain why one of them were given priority to others. The court's to ensure adequate justification of decisions falls within the limits of their institutional capacity and is the task to which they are best suited ${ }^{75}$.

71 CLEVER, op. cit., p. 118; Van RAEPENBUSCH, op. cit. pp. 509-510.

72 CLEVER, op. cit., pp. 158, 175. These arguments are affirmed by the judgement in the case Crispoltoni (ECJ: 5 October 1994, C-133/93, C-300/93 \& C-362/93, ECLI:EU:C:1994:364), wherein the Court stated that the appellant's arguments were based on the assumption, that misuse of powers may consist in the manifest unsuitability of a measure to the objective pursued, which means that it is necessary to examine the allegations in terms of the principle of proportionality ( $\left.\int 35\right)$.

73 STĘPKOWSKI, op. cit., pp. 232-239.

74 WADE, FORSYTH, op. cit., pp. 371-372.

75 WOOLF, JOWELL, Le SUEUR. op. cit., p. 598. 


\section{The legality and suitability as the criteria for the judicial review in the event of abuse of discretionary powers}

If abuse of discretionary powers means using it contrary to the purpose for which the legislature granted the authority with this type of powers, the key problem of separation of the criterion of legality and suitability appears. The abuse of discretionary powers approaches both these criteria in a unique way: legality is determined by a teleological interpretation of the power-granting provision. Thus, the following problem arises: how to distinguish suitability which is the legal determinant of the use of discretion by the authority from the suitability beyond the sphere of legality in a given situation.

The significance of the problem becomes particularly evident if we consider that all concepts of abuse of discretion were developed as an instrument of judicial review of public administration. Since the judicial review employs the criterion of lawfulness of the act, errors in the use of discretionary powers must constitute a violation of the legal norm. However, this does not solve the fundamental problems, because the question arises whether, and to what extent, there is a legal obligation to act in accordance with the criterion of suitability (Rechtspflicht zur Zweckmäßigkeit). To the extent that such a legal obligation exists, the inconsistency of the action with its objective will inevitably be a violation of the law also.

When analysing the problem of general obligation of the state to act purposefully, Robert Alexy points out that the content of such an obligation is the requirement to use only appropriate, necessary and properly balanced means (geeignete, erforderliche und richtig abgewogene Mitte). The point is, to what extent the implementation of this type of obligation is "judicially verifiable" (gerichtlich kontrollierbar). There is no doubt that in any democratic constitutional state, the obligation of purposeful action by public authority is something more than a mere political or moral duty ${ }^{76}$.

Due to the fact that legality of a measure is determined by the adjustment to the needs of the case, which indicates a link with suitability, the discussion arises among scholars whether the court only reviews legality, or also suitability.

Some authors argue that, the review of necessity in any case is not the review of suitabilty. If the measure is legal only when it is necessary, the authority has no other choice. It must use this measure if it is necessary and cannot use it if this criterion is not met. The judicial review does not cover the question of suitability ${ }^{77}$.

However, other scholars of law argue that the evolution of judicial review has led to a shift in the limits of suitability and legality of the act and to the mixing of these

76 ALEXY, Robert. Ermessensfehler. Juristenæeitung, 1986, no. 15-16, pp. 705-706.

77 DeLVOLVÉ, Pierre. Existe-t-il un contrôle de l'opportunité. In: Conseil constitutionnel et Conseil d'État. Paris: L.G.D.J., 1988, p. 294. ISBN 22-75-008268. 
criteria. According to Jean Paul Costa ${ }^{78}$ the introduction of the principle of proportionality allowed the Council of State to bypass the difficulty self-imposed by it. This difficulty results from the principle that the court, as the guardian of legality, does not control the suitability of administrative decisions.

If legality is understood as compliance with legal rules (which must be observed by the authority), while suitability is understood as fitness to the circumstances in which the decision was issued, in some cases the court simultaneously reviews both the legality and opportunity of the decision, i.e. its legality and its fitness to facts (adaptation aux faits). This is illustrated by examples of judgements in cases of administrative police. A measure is lawful only if it is proportional to the violation of public order, in other words: when it is respective to this violation. This is the definition of suitability. This applies also to the review of the use of discretionary powers by the administration. An example can be, referred to above, the classic judgement of the French Council of State in case Benjamin, in which it was considered that the prohibition to hold a public assembly is a disproportionate measure, because in reality there was no actual threat to public order. Looking at the body's motivation, the case involved an abuse of powers, as the mayor used a police measure (prohibition of assemblies) under the influence of trade union protests and, therefore, against the purpose of the conferred powers.

The interchangeability of review criteria, dictated by the need to find a suitable means of protection of an individual against arbitrariness of public administration, even at the expense of "dogmatic purity" and transparency of theoretical classifications, is also visible in the case law of English courts. The confirmation is Lord Templeman's argumentation in the case R. $v$. Inland Revenue Commission, ex parte Preston ${ }^{79}$ :

"In most cases in which the court has granted judicial review on grounds of ,unfairness" amounting

to abuse of power there has been some proven element of improper motive. (...) when they abused their powers by exercising or declining to exercise those powers in order to achieve objectives which were not the objectives for which the powers had been conferred"

This tendency to enhance control is worth preserving, as long as it allows the administrative court to play a full role as a defender of individuals, ensuring the compliance with standards of good administration ${ }^{80}$.

The key issue is to understand the fundamental principle that the role of the court is not to substitute the administration with regard to the merits of decisions.

78 COSTA, Jean-Paul. Le principe de proportionnalité dans la jurisprudence du Conseil d'État. Actualite Juridique: Droit Administratif, 1988, p. 434.

791985 A.C. 835 (864).

80 SERRAND, op. cit., pp. 921-923. Similarly in Belgian literature: BATSELE, MORTIER, SCARCEZ, op. cit., p. 717. 
An example of this may be the argumentation of Judge Laws in the case Somerset County Council, ex parte Fewings ${ }^{81}$. Trying to explain the essence of judicial review, Judge Laws stated:

"It is that, in most cases, the judicial review court is not concerned with the merits of the decision under review. The court does not ask itself the question "Is this decision right or wrong?" Far less does the judge ask himself whether he would himself arrived at the decision in question. [...] The only question for the judge is whether the decision taken by the body under review was one which it was legally permitted to take in the way it did'.

A likewise example is Lord Donaldson's discourse in the case Secretary of State for the Environment, ex parte Hammersmith and Fulham London Borough Council ${ }^{2}$ :

"The role of the judiciary is essentaily that of a referee (...) the moves made by the players and the tactics employed by the teams are matters entirely for them. The referee is only involved when it appears that some player has acted in breach of the rules. The referee may then stop the play and take soem remedia action but, tempting though it may be it, it is not for him to express any view on the skill of the players or how he would have acted in their position. Still less, following a breach of the rules, does he take over the position of one of the players. So too with the judiciary (...)".

The above efforts to justify and explain the essence of judicial review of discretionary power is supported by the concept of "judicial self-restraint" and the accompanying question of "unreviewable discretion". Courts try to be moderate in matters related to the implementation of administrative policy in certain "sensitive" areas (such as immigration law), to avoid being accused of forcing their own "policy" 83 . Therefore, courts are trying to adjust the intensity of review of discretionary powers to the character of a particular situation, so as not to excessively reduce the role of the administration in shaping and achieving objectives assumed.

The area where judicial self-restraint is seen is the issue of appropriate allocation of limited public funds, such as health services financed from public funds. Limited resources may lead to the need to make dramatic choices as part of the exercise of discretionary powers. An example of this may be the case R. v. Cambridge Health Authority ex. p. $B .^{84}$, in which the authority refused to finance a costly experimental therapy for a child suffering from leukemia, yet with a small chance for the success. The refusal was justified on the one hand by the nature of the therapy, which cannot be considered

81 High Court (Queens Bench Division): 10 February 1994, [1995] 1 All ER 513.

82 Court of Appeal: 4 October 1990, 3 All E.R. 589 (614).

83 BRINKTRINE, op. cit., p. 344. See also a statement by Judge Lawton in Case Laker Airways v. Department of Trade (Court of Appeal: 15. 12. 1976; [1977] Q.B. 643): “(...) Judges bave nothing to do with either policy making or the carrying out of policy. Their function is to decide wheter a minister has acted within the powers given bim by statute or common law".

84 Court of Appeal: 10 March 1995, [1995] 1 WLR 898. 
as the best possible solution in the interest of the child, on the other hand by the limited financial resources. The dramatic character of the case is well illustrated by Lord Bingham's statement:

"I have no doubt that in a perfect world any treatment which a patient, or a patient's family, sought would be provided if doctors were willing to give it, no matter how much it costs, particularly when a life was potentially at stake. It would however, in my view, be shutting one's eyes to the real world if the court were to proceed on the basis that we do live in such a world. It is common knowledge that health authorities of all kinds are constantly pressed to make ends meet. They cannot pay their nurses as much as they would like; they cannot provide all the treatments they would like; they cannot purchase all the extremely expensive medical equipment they would like; they cannot carry out all the research they would like; they cannot build all the hospitals and specialist units they would like. Difficult and agonising judgments have to be made as to how a limited budget is best allocated to the maximum advantage of the maximum number of patients. That is not a judgment which the court can make. In my judgment, it is not something that a bealth authority such as this authority can be fairly criticised for not advancing before the court'.

\section{Conclusions. The future of the concept}

When analysing the case law regarding the review of the exercise of discretionary powers, it is evident that the classic concept of abuse of powers has clearly lost its significance. Although it is still referred to in administrative law handbooks by scholars, it appears less and less frequently in the case law. At the same time, many authors note that, while applicants with persevering "enthusiasm" invoke charges of abuse of power, the courts are less and less concerned about these charges. The reasons for this phenomenon can be seen in the nature of the classically conceived concept of abuse of powers, which requires the assessment of intentional elements of the authority's action. On the one hand, this causes evidence finding difficulties, and on the other, it makes it difficult to formulate objectively verifiable arguments in a legal dispute regarding the legality of the act. As a result of these factors, the construct of abuse of power is superseded by other grounds of complaint that allow for the same effect of repealing the act, but are based on more transparent and objectively perceptible criteria (in particular the principle of proportionality or the concept of manifest error in assessment).

The evolution of the case-law has reduced the practical meaning of the classical concept of abuse of discretionary powers (detournement de pouvoir, Ermessensmissbrauch), although it did not undermine its theoretical basis. Simply, the courts, as well as the complainants, are less eager to use this concept, considering the instrument to be more difficult to apply and giving far less certain effects in the form of repealing a defective act. It is therefore not a change of dogmatic nature, but rather of practical nature. The theoretical foundations of classic concepts retain their value, although they have lost their practical significance. 
Despite the declining practical significance, the concept of abuse of powers remains an ultima ratio means to challenge administrative acts that are unacceptable from the point of view of the axiology of the legal system, the "ultimate weapon" of an administrative court judge. The value of this concept is also expressed in emphasizing the importance of the competence norms. Without denying the need for a restrictive interpretation of competence provisions, it must be recognized that each power of an administrative body has its own specific purpose. The use of powers for purposes other than that for which they were originally intended leads to an unacceptable restriction of the rights of the individual. A reference to the search for the purpose of the powers, characteristic of the concept of abuse of powers, does not blur the limits of interference, but on the contrary: allows them to be given a rational sense.

It should be noted that the prohibition of abuse of power under the European soft law is still one of the basic standards for exercising powers by a public administration body and one of the basic criteria for judicial review of public administration (art. 7 of the European Code of Good Administrative Behavior; Recommendation No. R (80)2 of the Committee of Ministers Concerning the Exercise of Discretionary Powers by Administrative Authorities ${ }^{85}$, Recommendation $\operatorname{Rec}(2004) 20$ of the Committee of Ministers to member states on judicial review of administrative acts $\left.{ }^{86}\right)$.

85 Among basic principles applicable to the exercise of discretionary powers by administrative authorities, the recommendation points to the principle of reasonableness: An administrative authority, when exercising a discretionary power: 1 . does not pursue a purpose other than that for which the power has been conferred (II.1).

86 According to the point 1.b, reffering to the scope of judicial review: "The tribunal should be able to review any violation of the law, including lack of competence, procedural impropriety and abuse of power". 